3.Ільющенкова К.Ю. Право на донорство в цивільному праві : дис. канд. юр. наук : 12.00.03. Київ, 2018. 284 с.

4.Брюховецька М.С. Цивільно-правове регулювання посмертного донорвсва : дис. канд. юр. наук : 12.00.03. Київ, 2017. 230 с.

5.Цивільний кодекс України від 16.01.2003 p. URL: http://zakon3.rada.gov.ua/laws/show/435$15 /$ conv?nreg=435-15\&find $=1 \&$ text $=\% \mathrm{E} 4 \% \mathrm{EE} \% \mathrm{ED} \% \mathrm{EE} \% \mathrm{~F} 0 \& \mathrm{x}=0 \& \mathrm{y}=0 \# \mathrm{w} 11$.

6. «Про застосування трансплантації анатомічних матеріалів людині»: Закон України від 28.02.2019 №2694. Відомості Верховної Ради. URL: https://zakon.rada.gov.ua/laws/show/2427-19

7.Martin Wilkinson The Donation of Human Organs. Stanford Encyclopedia of Philosophy. URL: https://plato.stanford.edu/entries/organ-donation/ .

8. Shaw D. Presumed consent to organ donation and the family overrule. Journal of the Intensive Care Society. 2017. URL: https://www.ncbi.nlm.nih.gov/pmc/articles/PMC5606427/.

9. Анализ опыта медиативной практики стран ближнего зарубежья (Белоруссии, Молдовы, Казахстана, Грузии, Украины, Армении и др.). Бюллетень Федерального Института Медиации. 2013. C. 206.

УДК $347.91 / .95$

DOI https://doi.org/10.32844/2618-1258.2019.3-2.13

ЛАБАНЬ О.О.

\title{
ЗАХИСТ ПРАВ ТА ІНТЕРЕСІВ ВІДПОВІДАЧА ПІД ЧАС ЗАБЕЗПЕЧЕННЯ ПОЗОВУ В ЦИВІЛЬНОМУ СУДОЧИНСТВІ
}

У статті досліджуються особливості захисту прав та інтересів відповідача під час забезпечення позову. Автор констатує, що послідовна реалізація принципу рівності сторін у цивільному процесі вимагає, що відповідачу, щодо якого було застосовано заходи забезпечення позову, було надано належний механізм захисту своїх прав. Такі заходи захисту, як і саме забезпечення позову, можуть бути застосовані до подання позовної заяви. Прийняті за заявою забезпечувальні заходи не повинні спричиняти відповідачеві невиправданих збитків, у зв'язку з чим суд наділений правом вимагати від позивача певних гарантій, а також відповідач наділений правом зустрічного забезпечення.

Реалізація принципів змагальності та рівності сторін повинна гарантувати відповідачу рівні з позивачем можливості для захисту своїх прав та інтересів у процесі реалізації заходів із забезпечення позову.

Одним із способів захисту відповідача в межах забезпечення позову автор визнає оскарження ухвали про забезпечення позову. Водночас таке оскарження не зупиняє процесу забезпечення до моменту задоволення скарги про скасування ували про забезпечення позову чи зміни одного виду забезпечення на інший.

У статті автор досліджує зустрічне забезпечення позову процесуальним засобом захисту відповідача, що має, по суті, ідентичні ознаки із самим забезпеченням позову і також повинен відповідати принципам змагальності, рівності і пропорційності цивільного судочинства, що теж мають місце у разі застосування зустрічного забезпечення.

Автор визнає заміну одних заходів забезпечення позову іншими способом захисту відповідача від забезпечення позову. У статті також досліджено проблему відповідальності за збитки відповідача, що спричинені забезпечувальними заходами. Розкрито умови, за яких такі збитки можуть бути відшкодовані.

(C) ЛАБАНЬ О.О. - головний спеціаліст відділу розгляду звернень та надання публічної інформації секретаріату (Касаційний адміністративний суд апарату Верховного Суду) 
Автор припускає можливість запровадження в національному законодавстві механізму подання відповідачем захисного документа як додаткового способу захисту відповідача. На думку автора, це значно знизить ризик прийняття проти нього необгрунтованих заходів щодо забезпечення позову, оскільки подача захисного документа вимагала б від відповідача належної аргументації з ії підкріпленням доказами.

Ключові слова: позивач, відповідач, забезпечення позову, зустрічне забезпечення, способи захисту, захисний документ.

The article explores the features of the defendant's rights and interest's protection in securing a claim. The author states that the consistent implementation of the principle of equality of arms in the civil process requires that the defendant in respect of whom the measures of the claim have been applied have been provided with an adequate mechanism to protect their rights. Such safeguards as the lawsuit itself can be applied to the application. The security measures taken on the application should not cause the defendant unjustified damages, and therefore the court is empowered to demand from the plaintiff certain guarantees, and the defendant is empowered with the right of counterclaim.

The implementation of the principles of competitiveness and equality of parties must guarantee the defendant level with the plaintiff the opportunity to protect their rights and interests in the course of implementing measures to secure a claim.

One way to defend a defendant in securing a claim is the author recognizes the appeal against the order securing the claim. However, such an appeal does not suspend the process of securing until the complaint about the cancellation of the claim for securing a claim or changing one type of security to another is satisfied.

In the article, the author examines the counterclaim for the defendant's procedural remedy, which has substantially identical features to the claim, and must also comply with the principles of competitiveness, equality and proportionality of civil proceedings, which also apply when counterclaims are applied. The author acknowledges the replacement of certain measures of securing the claim by another way of protecting the defendant from securing the claim.

The article investigates the problem of liability for the defendant's losses caused by security measures. The conditions under which such damages can be compensated are disclosed.

The author assumes the possibility of introducing in the national legislation a mechanism for the defendant to submit a security document as an additional way of protecting the speaker. According to the author, this will significantly reduce the risk of taking unreasonable measures against him to secure a claim, since the filing of a security document would require the defendant to have a proper argument with its supporting evidence.

Key words: plaintiff, defendant, claim, counterclaim, defense, security document.

Вступ. Забезпечення позову в цивільному процесі передбачає можливість прийняття судом у встановлених законом випадках заходів, спрямованих на виконання майнових чи інших вимог позивача до відповідача, i, по суті, визнається способом захисту майнових прав позивача.

У деяких випадках забезпечення позову, прийняте в інтересах позивача, може заподіяти необгрунтовану шкоду інтересам відповідача. У зв'язку із цим виникає необхідність детальної регламентації способів і засобів захисту прав та інтересів відповідача від необгрунтованих майнових втрат.

Тому захистом прав та інтересів відповідача під час вжиття заходів щодо забезпечення позову необхідно визнавати комплекс врегульованих цивільним процесуальним законом заходів, спрямованих на охорону прав і законних інтересів особи, щодо якої приймаються такі заходи.

Проблематику захисту прав сторін загалом і відповідача зокрема, в тому числі в процесі вжиття заходів із забезпечення позову, досліджували такі процесуалісти, як: Н.С. Алєксєєва, Л.І. Анісімова, А.Н. Балашов, С.С. Бичкова, Н.Л. Бондаренко-Зелінська, Г.Д. Васильєва, Н.М. Васильченко, 
М.А. Гурвич, П.П. Колєсов, І.С. Комаров, Д.Д. Луспеник, Н.М. Трашкова В.І. Тертишніков, В.В. Ярков та інші. Проте теоретичне розроблення проблем захисту відповідача в межах забезпечення позову, зважаючи на новели, запроваджені цивільним процесуальним законодавством, що стосуються інституту зустрічного забезпечення, потребують додаткового дослідження та розроблення.

Постановка завдання. Метою наукової статті є дослідження особливостей різних способів захисту прав та інтересів відповідача під час забезпечення позову в цивільному судочинстві в контексті принципів рівності та змагальності сторін.

Результати дослідження. Кожна сторона судового процесу повинна мати достатню можливість представляти свою позицію у справі в умовах, які не будуть ставити її в суттєво несприятливіше становище щодо протилежної сторони, тобто в умовах, в яких жодна зі сторін не має явної переваги. По суті, на вказаному грунтується принцип рівності сторін у цивільному процесі.

Відповідач у разі пред’явлення до нього необгрунтованої вимоги про забезпечення позову може виявитися в настільки несприятливому, порівняно з позивачем, становищі, що змушений буде відмовитися від продовження судового розгляду, навіть якщо впевнений, що позов за результатами розгляду не буде задоволений.

Отже, позивачу і відповідачу повинні бути створені рівні можливості для реалізації права на судовий захист, зокрема, під час застосування в інтересах позивача заходів щодо забезпечення позову відповідачу повинна бути гарантована можливість захисту його прав від безпідставного або ж необгрунтованого забезпечення.

Не зупиняючись на констатації порядку та процедури забезпечення позову, зауважимо лише, що Цивільний процесуальний кодекс (далі - ЦПК) України [1] в межах гл. 10 регламентує певний обсяг заходів, спрямованих на захист прав відповідача.

Ч. 1 ст. 150 ЦПК України передбачено види способів забезпечення позову із зазначенням, що вказаний у нормі перелік не є вичерпним і можуть бути застосовані інші способи забезпечення позову.

Тут варто зазначити, що щоразу, коли так чи інакше в нормі права виникає необхідність визначення певного переліку, виникає питання про доцільність його існування у вичерпному чи невичерпному характері. Оскільки процесуальне законодавство з позиції дуалізму права належить до сфери публічного права, то це означає, що суд керується лише нормами, що знайшли відображення в законі. В аналізованій ситуації суд наділяється правом вживати інших заходів, необхідних для забезпечення ефективного захисту або поновлення порушених чи оспорюваних прав та інтересів, якщо такий захист або поновлення не забезпечуються заходами, зазначеними в пунктах 1-9 ч. 1 ст. 150 ЦПК України. Якими можуть бути такі способи забезпечення і чи будуть такі способи так чи інакше впливати на порушення прав та інтересів відповідача?

По суті, суд повинен вирішити питання, спираючись на відповідний юридичний прийом, іменований і в доктрині процесуального права, і законодавцем аналогією. Застосування аналогії зумовлюється низкою правил, одне з яких говорить, що текстуально норму для використання за аналогією потрібно шукати в тій самій галузі права і тільки за її відсутності там переходити до пошуку в інших галузях.

Аналіз ЦПК України не дає змоги визначити такі «інші» заходи забезпечення позову. Полегшити пошук процесуальної норми за межами ЦПК України, яку суд має право застосувати в порядку аналогії, можуть такі висновки, отримані в процесі тлумачення поняття «інші заходи» щодо забезпечення позову. По-перше, оскільки поняття належить до розряду родових, то законодавець повинен закріплювати окремі види подібних заходів; по-друге, воно є оціночним, що, по суті, відображає тенденції нормотворчості пострадянського періоду, конкретним змістом його повинен наповнити саме суд, при цьому він спирається на мету, яку законодавець покладає на подібний процесуальний захід - гарантувати позивачу можливість отримати задоволення його вимоги від відповідача в разі визнання цієї вимоги судом. Зрозуміло, суд застосовує забезпечувальний захід у ситуації небезпеки, що незабезпечення позову може позбавити позивача можливості отримати задоволення, тобто суд не тільки вирішує справу по суті, але й здійснює дії, спрямовані на реальне виконання свого рішення в майбутньому.

У цьому контексті варто також зазначити, що заходи захисту відповідача, передбачені під час забезпечення позову, можуть бути застосовані до моменту прийняття позовної заяви до розгляду, що, по суті, буде визначати особливий момент, коли особа стає відповідачем, на відміну від інших способів, таких як зустрічний позов і відзив на позовну заяву.

Одним із засобів захисту відповідача в межах забезпечення позову виступає передбачена можливість оскарження ухвали про забезпечення позову. Однак оскарження такої ухвали не зу- 
пиняє процесу забезпечення до моменту задоволення скарги про скасування ували про забезпечення позову чи зміни одного виду забезпечення на інший.

У разі, коли оскаржується ухвала в межах позовного провадження, то до апеляційного суду направляються копії матеріалів (копії позовної заяви і заяви про забезпечення позову, оригінал ухвали, ухвала про відкриття провадження тощо), необхідних для розгляду скарги.

У разі, коли ухвала про забезпечення позову передує поданню позовної заяви, у разі оскарження ухвали про забезпечення позову необхідно направити до суду апеляційної інстанції відповідні матеріали (копії позовної заяви і заяви про забезпечення позову, оригінал оскаржуваної постанови, копії документів про звернення іiї до виконання тощо), після чого вживаються заходи щодо подальшого розгляду справи по суті заявлених вимог.

Цивільним процесуальним законодавством України передбачено й інші способи захисту прав особи, проти якої було направлено заяву про вжиття заходів щодо забезпечення позову.

У зв'язку із цим важливо вказати, що одним із нововведень у ЦПК України, які було внесено Законом України від 3 жовтня 2017 року, стало виокремлення та детальна регламентація інституту зустрічного забезпечення.

Запровадження вказаного інституту покликане запобігати зловживанням позивача своїми процесуальними правами. Чинна редакція ЦПК України розглядає зустрічне забезпечення як механізм захисту прав відповідача від можливих збитків, завданих забезпеченням позову [2]. Зустрічне забезпечення позову варто визнавати процесуальним засобом захисту відповідача, що має, по суті, ідентичні ознаки із самим забезпеченням позову і також повинен відповідати принципам змагальності, рівності і пропорційності цивільного судочинства, які теж мають місце у разі застосування зустрічного забезпечення. Отож зустрічне забезпечення варто розглядати як механізм створення певного балансу та рівноваги між правами та інтересами позивача та відповідача під час розгляду справи. Хоча не можна сказати, що зустрічне забезпечення $є$ новим інститутом для національного процесуального законодавства, адже попередня редакція ЦПК України в ч. 4 ст. 153 містила норму, з якої випливав обов'язок суду вимагати від позивача забезпечити свою вимогу заставою, достатньою для того, щоб запобігти зловживанню забезпечення позову. Також зустрічне забезпечення відоме і міжнародним правопорядкам. До прикладу, в доповіді Асоціації міжнародного права «Про забезпечувальні заходи в міжнародному цивільному процесі» зазначається, що суд повинен бути наділений такими повноваженнями, що сприятимуть вимозі від позивача гарантій відшкодування збитків, завданих забезпеченням позову відповідачу чи третій стороні. По суті, зустрічне забезпечення $\epsilon$ певною гарантією збереження «status-quo» між сторонами до ухвалення остаточного рішення суду за суттю справи [3].

3 тексту ЦПК України можна зробити висновок про те, що суд має право, а не обов’язок із вжиття заходів зустрічного забезпечення, проте ЦПК України містить кілька винятків. Наприклад, суд зобов'язаний застосувати зустрічне забезпечення позову, якщо суду надано докази того, що майновий стан позивача або його дії щодо відчуження майна чи інші дії можуть ускладнити або зробити неможливим виконання рішення суду про відшкодування збитків відповідача [4]. На вказаному акцентує також свою увагу Верховний Суд у результаті перегляду справи № 753/2380/18-ц в Постанові від 10 квітня 2019 року (касаційне провадження № 61-38399св18) [5], який вказує, що вжиття заходів зустрічного забезпечення у розумінні ч. 3 ст. 154 Цивільного процесуального кодексу України є не диспозитивним правом суду, а його обов'язком.

Ст. 156 ЦПК України передбачає можливість заміни одних заходів щодо забезпечення позову іншими. Текст вказаної норми не містить вказівки на коло тих суб'єктів, що мають право заявляти таке клопотання, вказуючи лише на учасника справи. 3 цього можна логічно припустити, що заміна одних заходів забезпечення позову іншими може також бути визнано способом захисту відповідача від забезпечення позову. Ухвала про зміну заходу забезпечення позову тягне за собою виникнення в суду права зміни способу зустрічного забезпечення. Однак ЦПК України не містить підстав для подання таких клопотань і переліку обставин, коли заміна способу забезпечення чи зустрічного забезпечення можливі.

Ще одним способом захисту інтересів відповідача під час вжиття заходів із забезпечення позову є відшкодування збитків відповідача, спричинених забезпеченням позову, що передбачено ст. 159 ЦПК України.

Торкаючись характеристики цього права відповідача, важливо зазначити, що воно має умовний характер, тобто може бути здійснене не у всіх випадках, а тільки під час настання таких умов: а) позивачу в задоволенні позову буде відмовлено повністю або частково; б) рішення, яким позивачу в позові відмовлено, вступило в законну силу; в) збитки відповідачу буде заподіяно саме заходами забезпечення позову. 
Спроба з'ясувати правову природу відшкодування позивачем або іншою особою збитків відповідача, завданих заходами забезпечення позову, привела деяких процесуалістів до висновку, що в такому разі настає зобов'язання із заподіяння шкоди $[6 ; 12]$.

Однак ми переконані, що така позиція, яка розглядає покладання відшкодування збитків відповідача на позивача чи іншу особу, як зобов'язання із заподіяння шкоди, не досить обгрунтована. Це пояснюється тим, що незалежно від того, хто з осіб, які беруть участь у справі, заявив клопотання про вжиття заходів щодо забезпечення позову, рішення може прийняти тільки суд. Отже, не діями позивача, а діями суду вживаються заходи щодо забезпечення позову. Очевидним $\epsilon$ і те, що збитки відповідача в такій ситуації завжди $є$ результатом поведінки суду, але не осіб, які беруть участь у справі.

Позивачі, що звертаються до суду з клопотанням про забезпечення позову, діють правомірно, вони реалізують своє суб'єктивне право, а тому, на нашу думку, дещо неправильною є позиція, за якою до позивача застосовуватиметься санкція у вигляді відшкодування збитків відповідачу, коли позивач лише ініціював перед судом питання про забезпечення своїх вимог.

У процесуальній літературі висловлювалася думка, що позивач, вимагаючи забезпечення позову, повинен знати, що він відповідає за обгрунтованість цих заходів. Така позиція підтверджується нормою ч. 1 ст. 151 ЦПК України, де вказується, що в заяві про забезпечення позову має бути вказано предмет позову, а також обгрунтування необхідності застосування забезпечення позову. Тому відшкодування збитків відповідача не може розцінюватися як відповідальність за необгрунтоване клопотання перед судом, а лише $є$ заходом захисту прав відповідача.

Позивач, відчуваючи необхідність у забезпеченні позову, буде щоразу думати про ті збитки, які можуть виникнути у відповідача у зв'язку із задоволенням його права. 3 огляду на це в цьому випадку ми зустрічаємося з правовим регулюванням ситуації, коли відбувається зіткнення інтересів відповідача та позивача.

Законодавством країн може бути передбачено інші способи захисту відповідача від забезпечення позову. Наприклад, судовій практиці Німеччини відомий такий спосіб захисту прав відповідача, що дає йому змогу ще до пред’явлення заяви про вжиття заходів забезпечення позову подати до суду так званий «захисний документ» (Schutzschrift) [7, с. 787]. Для подачі захисного документа досить припущення відповідача, що позивач може вимагати застосування такого заходу.

У такому захисному документі міститься клопотання потенційного відповідача про відмову в прийнятті заходів забезпечення позову або про розгляд судом заяви про вжиття таких заходів неодмінно в судовому засіданні.

Слід зазначити, що можливість подачі захисного документа не передбачена в законодавстві Німеччини, така традиція склалась лише в судовій практиці, починаючи від розгляду справ про недобросовісну конкуренцію, а сьогодні є визнаним способом захисту інтересів відповідача під час прийняття заходів щодо забезпечення позову. На думку низки німецьких авторів, суд повинен брати до уваги такий захисний документ на основі гарантованого п. 1 ст. 103 Основного закону Німеччини права кожної особи бути вислуханою судом [7, с. 788].

Однак подання такого документа не позбавляє права позивача подати заяву про забезпечення позову до подання позовної заяви або ж процесу розгляду справи по суті. За наявності такого документа суд зобов'язаний в такому разі надати особі, що клопоче про вжиття заходів забезпечення позову, можливість відповісти на такий документ під час призначеного судового засідання.

Звичайно, можна обережно припустити доцільність запровадження такого способу захисту у вітчизняному цивільному процесуальному законодавстві, але з дотриманням певних пересторог. 3 одного боку, запровадження такого способу захисту відповідача забезпечить додатковий важіль для дотримання балансу інтересів сторін у цивільному процесі. Це значно знизило б ризик прийняття проти нього необгрунтованих заходів щодо забезпечення позову, оскільки подача захисного документа вимагала б від відповідача належної аргументації з ії підкріпленням доказами. 3 іншого - при цьому не порушувалися б права позивача (заявника), оскільки у нього була б можливість представити суду свої аргументовані заперечення на захисний документ.

Однак впровадження в національне цивільне процесуальне законодавство зазначеного способу захисту прав відповідача, на нашу думку, повинно здійснюватися 3 деякими обмеженнями, що відповідають цілям і завданням цивільного судочинства, а також потребам правозастосовної практики. Зокрема, надання відповідачу права пред’явити до суду захисний документ не повинно суперечити такій важливій характеристиці заходів щодо забезпечення позову, як їхній невідкладний характер. 
Висновки. Підсумовуючи викладене, важливо зазначити, послідовна реалізація принципу рівності сторін у цивільному процесі вимагає, що відповідачу, щодо якого було застосовано заходи забезпечення позову, було надано належний механізм захисту своїх прав. Такі заходи захисту, як і саме забезпечення позову, можуть бути застосовані до подання позовної заяви. Прийняті за заявою забезпечувальні заходи не повинні спричиняти відповідачеві невиправданих збитків, у зв'язку із чим суд наділений правом вимагати від позивача певних гарантій, а також відповідач наділений правом зустрічного забезпечення.

Реалізація принципів змагальності та рівності сторін повинна гарантувати відповідачу рівні з позивачем можливості для захисту своїх прав та інтересів у процесі реалізації заходів із забезпечення позову.

\section{Список використаних джерел:}

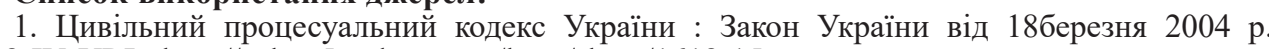
№ 1618-IV. URL: http://zakon5.rada.gov.ua/laws/show/1618-15.

2. Шурин O.А. Інститут забезпечення позову: теоретичні та практичні проблеми реалізації. Прикарпатський юридичний вісник : зб. наук. пр. / Нац. ун-т «Одес. юрид. акад.». Івано-Франківськ, 2018. Вип. 1 (22). С. 171-174.

3. Луспеник Д.Д. Зустрічне забезпечення. Кілька складних питань щодо застосування нового інституту, з якими стикнуться судді. Закон і бізнес. 2017. № 34 (1332). URL: http://zib.com.ua/ ua/print/130073-kilka_skladnih_pitan_schodo_zastosuvannya_zustrichnogo_zabez.html.

4. Перцова O.I. Чи можуть заходи забезпечення позову бути скасовані або оскаржені. URL: https://lhs.net.ua/ua-chy-mozhut-zakhody-zabezpechennia-pozovu-buty-skasovani-abo-oskarzhenipoiasnyla-olena-pertsova-radnyk-iuf-aequo-ru-mohut-ly-mery-obespechenyia-yska-byt-otmenenyyly-osporeny-poiasnyla-elena-pert-2.

5. Постанова Верховного Суду від 10 квітня 2019 р. (касаційне провадження № 61-38399св18). URL: http://www.reyestr.court.gov.ua/Review/81288258.

6. Цихоцкий А.В. Секвестр как вид обеспечительных мер в современном гражданском процессе. Пролог. Все о праве. 2013. № 4. С. 11-14.

7. Schuschke W., Walker W. Vollstreckung und Vorlaeufiger Rechtsschutz. Koeln, 2008. 2548 s.

УДК 347.941

DOI https://doi.org/10.32844/2618-1258.2019.3-2.14

ЛУК’ЯНЧУК О.I.

\section{ПІКЛУВАННЯ ПРО НЕПРАЦЕЗДАТНИХ, НЕМІЧНИХ БАТЬКІВ: ЗАКОНОДАВЧЕ ЗАКРІПЛЕННЯ МОРАЛЬНОГО ОБОВ'ЯЗКУ}

У статті здійснено аналіз змісту обов'язку дитини, повнолітніх дочки та сина піклуватися про своїх батьків. Проведено аналіз передумов, що сприяли законодавчому закріпленню цього обов'язку. Встановлено коло осіб, зобов'язаних піклуватися про батьків. Надано правову характеристику. Завдяки системному аналізу законодавства запропоновано юридичне визначення стану «немічності». Встановлено, що стан немічності за своїми ознаками збігається з ознаками безпорадного стану. Обгрунтовано необхідність на законодавчому рівні закріпити визначення стану немічності, який, у свою чергу, відповідає ознакам непрацездатності. Встановлено відмінність між покладеним на дітей обов'язком піклуватися про своїх батьків (ст. 172 Сімейного кодексу (далі - СК) України), обов'язком повнолітніх дочки, сина брати участь у додаткових витратах на батьків, зумовлених тяжкою хворобою, інвалідністю або немічністю (ст. 203 СК України), та правом батьків, які

(C) ЛУК’ЯНЧУК О.І. - аспірант кафедри цивільного права і процесу (Національна академія внутрішніх справ) 